\title{
Author Correction: Genomic evidence consistent with antagonistic pleiotropy may help explain the evolutionary maintenance of same-sex sexual behaviour in humans
}

Brendan P. Zietsch (iD, Morgan J. Sidari (D), Abdel Abdellaoui (iD, Robert Maier (D), Niklas Långström (D), Shengru Guo, Gary W. Beecham, Eden R. Martin, Alan R. Sanders (D) and Karin J. H. Verweij (D)

Correction to: Nature Human Behaviour https://doi.org/10.1038/s41562-021-01168-8, published online 23 August 2021

In the version of this Article initially published, an error appeared in Table 1, eighth column, center row, where the mean number on the Attractiveness scale for Women was reported as "0.49" but instead should have read " 3.49 ." This error does not affect the conclusions presented in the paper.

This correction has been made to the print and online versions of this Article.

Published online: 13 September 2021

https://doi.org/10.1038/s41562-021-01210-9

(c) The Author(s), under exclusive licence to Springer Nature Limited 2021 